Ростовский институт повышения квалификации и профессиональной переподготовки работников образования, г. Ростов-на-Дону, Российская Федераиия

\title{
ПСИХОЛОГО-ПЕДАГОГИЧЕСКИЕ АСПЕКТЫ РЕФЛЕКСИВНОГО УПРАВЛЕНИЯ УЧЕБНОЙ ДЕЯТЕЛЬНОСТЬЮ ОБУЧАЮЩИХСЯ В УСЛОВИЯХ ИЗМЕНЕНИЯ СИСТЕМЫ ОЦЕНИВАНИЯ ПРИ ФОРМИРОВАНИИ ЛИЧНОСТНЫХ РЕЗУ ЛЬТАТОВ
}

\begin{abstract}
АНнотАЦия. Статья посвящена результатам исследования в области формирования личностных результатов в процессе специально организованных условий учебной деятельности школьников. Рассматривается история развития данного вопроса и представлена авторская интерпретация понимания личностных результатов образования в условиях реализации федеральных государственных образовательных стандартов. Ключевой идеей при этом является мысль автора статьи о тесной сопряженности федеральных государственных образовательных стандартов и рефлексии основных участников образовательного процесса. Анализируются требования профессионального стандарта «Педагог» к составу психолого-педагогических компетенций современного педагога, среди которых особое место занимают компетенции, связанные с управлением качества системы «учитель - ученик», знанием о внутренних ресурсах учения и управления учебной деятельностью обучающихся. Особое внимание обращено на технологии рефлексивного управления учебной деятельностью детей. Раскрыты психолого-педагогические аспекты рефлексивного управления учебной деятельностью школьников и примеры применения коучинговой технологии, основанной на идее постановки открытых вопросов, актуализирующих субъектную и рефлексивную позицию ученика.

кЛючЕВЫЕ словА. Субъектность; рефлексивная позиция; личностное развитие; личностные результаты образовательной деятельности; смыслы образования; образовательные стандарты; рефлексивное управление; система оценивания; рефлексивная самооценка; рефлексия в структуре самосознания; рефлексивное самосознание; технология рефлексивного управления; коучинговые (вопросные) технологии. ИНФОРМАЦИЯ О СТАТЬЕ. Дата поступления 16 марта 2016 г.; дата принятия к печати 17 июня 2016 г.; дата онлайн-размещения 29 июля 2016 г.
\end{abstract}

N. P. Epova

Rostov Institute of Training and Professional Retraining of Educators, Rostov-on-Don, Russian Federation

\section{PSYCHOLOGICAL AND PEDAGOGICAL ASPECTS \\ OF REFLEXIVE MANAGEMENT OF SCHOOL STUDENTS' EDUCATIONAL ACTIVITY IN TERMS OF CHANGING ASSESSMENT SYSTEM IN DEVELOPING PERSONAL RESULTS}

ABSTRACT. The article is devoted to results of research in the field of developing personal results in the course of specially arranged environment for educational activities of school students. It considers history of development of this issue and presents the author's interpretation of understanding personal results of education in terms of implementing federal state educational standards. In this context, the key idea of the author is close associativity of the Federal State Educational Standards and the reflection of the main participants of the educational process. The article analyses the requirements of the professional standard «Pedagoque» to the content of the psychological and pedagogical competences of to-day's pedagogue that involve specifically important competences connected with managing the quality of the system «teacher - pupil», with knowledge

(ㄷ) Н. П.Эпова, 2016

\section{Baikal Research Journal}

электронный научный журнал Байкальского государственного университета 
of internal resources of teaching and management of the students' learning activities. Special attention is paid to technology of reflexive management of educational activities of children which, according to the author, contain huge resources for formation of their subject (reflexive) position. In article psychology and pedagogical aspects of technology of reflexive management of educational activity of school students and examples of application of the kouchingovy technology based on idea of statement of the open questions staticizing a subject and reflexive position of the pupil are opened.

KEYWORDS. Subjectivity; reflexive position; personal development; personal results of educational activity; meanings of education; educational standards; reflexive management; system of estimation; reflexive self-assessment; a reflection in structure of consciousness; reflexive consciousness; technology of reflexive management; kouching (voprosny) technologies.

ARTICLE INFO. Received March 16, 2016; accepted June 17, 2016; available online July 29, 2016.

В наступившем веке «трансформаций и субъектности» образование нацелено на получение важнейших личностных результатов развития учащегося в ходе образовательной деятельности. Федеральные государственные образовательные стандарты (ФГОС) нового поколения призваны консолидировать общество в условиях роста его разнообразия, обеспечить формирование российской гражданской идентичности, получить ученика, мотивированного к познанию, критически мыслящего, готового отвечать за свои действия и их последствия, принимающего ценность личности, жизни, общества и человечества.

ФГОС вызваны необходимостью становления самостоятельной субъектной позиции школьника, формирования способности личности к самоизменению, саморазвитию и самовоспитанию, позитивной адаптации и социализации в условиях меняющегося мира (К. А. Абульханова, А. Г. Асмолов, А. В. Брушлинский, С. Л. Рубинштейн, Г. П. Звенигородская, М. М. Поташник).

Формирование позиции субъекта учебной деятельности становится целью и особого рода содержанием образования (А. А. Бодалев, В. В. Давыдов, М. М. Поташник, Г. В. Самусева, В. И. Слободчиков, Г. А. Цукерман). Актуальным является выстраивание личностно-ориентированных моделей образовательного процесса, рассчитанных на развитие и саморазвитие учащихся как подлинных субъектов образования, активизацию их инициативы, получение значимых личностных результатов.

Для более глубокого понимания содержания современных результатов образовательной деятельности следует рассмотреть теоретические аспекты и немного обратиться к истории вопроса понятия «результаты образования». В 2002 г. в книге Т. И. Шамовой «Управление образовательными системами» речь идет об образовательных системах, образовательном процессе и его содержании, управлении образовательными системами и использовании образовательных технологий [1]. А. Б. Воронцов отмечает, что в 1998 г. использовалось понятие «предметные результаты», а в 2004 г. применяли уже такие термины, как общие умения, навыки и способы деятельности, предметные результаты. В 2009 г. заговорили о личностных, метапредметных и предметных результатах образования.

Известные ученые А. В. Хуторской, И. Я. Лернер, М. Н. Скаткин предлагают рассматривать образовательные результаты как социальный опыт (компетентности) учащегося, приобретенный в ходе освоения образовательных программ, обладающий свойством широты переноса и применения вне рамок учебного предмета.

Разработчик принципов личностно-ориентированного обучения и теории образования как «образовывания» человека А. В. Хуторской рассуждает о развитии личностных качеств ученика в ходе освоения изучаемых предметов и при осуществлении совместной деятельности учителя и ребенка. Ученый вводит понятие «личностное образовательное приращение» (знания, чувства, способности, способы,

\section{Baikal Research Journal}

электронный научный журнал Байкальского государственного университета 
опыт), которое наряду с внутренним ростом учащегося считает главным показателем личностной ориентации при обучении. Мы согласны с ученым, который пишет: «Личный результат каждого ребенка - это самое важное в его образовании. Этот результат не приходит к нему снаружи, а произрастает внутри. Личный рост нужно организовать» [2].

Авторы концепции образованности О. Е. Лебедев, А. П. Тряпицына, Е. И. Казакова выделяют две основные характеристики результатов образования, одной из которых является образованность как индивидуально-личностный результат образования, качество личности, заключающееся в способности самостоятельно решать проблемы, опираясь на освоенный социальный опыт. Обратим внимание на мнение В. В. Юдина, который утверждает, что в теории дидактики нет общей структурной модели образовательного результата, в которой нашли бы отражение запросы практиков, востребующие новые грани личности, нет шкалы, по которой можно было бы различить традиционный и новый образовательный результат.

На данном этапе развития системы образования предлагается современное понимание образовательных результатов (А. Г. Асмолов, А. М. Кондаков, Н. Д. Никандров, А. Б. Воронцов). Это понимание связанно со сменой базовой парадигмы образования со «знаниевой» на системно-деятельностную, в рамках которой результаты образования должны быть прямо связаны с направлением личностного развития, формированием качеств личности [3; 4]. Личностное развитие учащихся определяется характером организации их деятельности, в первую очередь учебной. Новые образовательные стандарты направлены на реализацию ведущих теоретических положений Л. С. Выготского, А. Н. Леонтьева, В. В. Давыдова, Л. В. Занкова о целостном подходе к исследованию личности ребенка, о необходимости общего развития школьников в процессе обучения, предполагая, прежде всего, личностное развитие. Процесс учения понимается не только как усвоение системы знаний, умений и навыков, составляющих инструментальную основу компетенций учащегося, но и как процесс развития личности, обретения духовно-нравственного и социального опыта.

Стержнем ФГОС является системно-деятельностный подход, разворачивающий внимание педагога в сторону процесса освоения способов действий, чем в сторону усвоения б льшего количества знаний. В связи с этим педагогу необходимо понимать стратегию мышления и действий ученика, отражать его состояние, для того чтобы оказать ему действенную помощь именно в способе получения знаний и их обработке, а не в приобретении фактов [5, с. 26]. Необходимо управлять учебной деятельностью. Весьма важными являются профессиональные компетенции педагога, которые определяются современной практикой и профессиональным стандартом педагогической деятельности «Педагог»:

- управление качеством системы «учитель - ученик» ;

- знания о внутренних ресурсах учения и управления учебной деятельностью;

- выбор оптимального решения для проектирования и реализации индивидуальной педагогической помощи учащемуся;

- выстраивание алгоритма управления проектированием изучения учебной темы и постановка целей ученика и учителя;

- использование системы критериального оценивания образовательных результатов школьников.

Практика показывает, что в реальности это самые «запаздывающие» компетенции современного педагога [6, с 10].

Уместно привести результаты анализа текста Профстандарта в разделе «3.1. Обучение. Воспитание. Развитие», который показал очевидное преобладание требований к владению учителем управленческой компетенцией (управление учебной деятельностью детей) (38 требований). На втором месте по количеству требований -

\section{Baikal Research Journal}

электронный научный журнал Байкальского государственного университета 
психолого-педагогическая компетенция (знание особенностей детей, создание комфортной развивающей психологически безопасной среды учебной деятельности и т. д.) (33 требования). Профстандарт предъявляет 28 требований к коммуникативной компетенции педагога, 15 и 16 требований, соответственно, относятся к валеологической и предметно-методологической компетенциям. Это еще больше доказывает актуальность затронутых нами вопросов [6, с. 11]. Значимая роль отводится рефлексивным умениям самого педагога, который способен понять глубинные задачи новых образовательных стандартов, не боится переделывать себя и отказаться от прежнего опыта, продемонстрировать субъектную позицию [7, с. 49].

По мнению М. М. Поташника, введение ФГОС включает шесть принципиальных новшеств, первое из которых - обеспечение и реализация только субъектной позиции учителя и ученика в образовательной деятельности" [7, с. 45]. М. Левит также признает субъектную позицию учителя и ученика главной психологической установкой, без которой освоение ФГОС невозможно. Отметим, что позиция субъекта всегда рефлексивна (т. е. субъект всегда рефлексивен), и поэтому педагогу следует формировать рефлексивную (субъектную) позицию обучающегося, уметь организовать конструктивный диалог, обеспечивающий ее дальнейшее развитие. Бесспорно, педагогу самому следует быть субъектом своей педагогической деятельности и жизни, развивать и совершенствовать собственные рефлексивные умения и компетенции.

Учителю с субъектной позицией, пишет М. Поташник, нужно проявить «недюжинную волю, чтобы отказаться от монологичного объяснения нового материала на всех уроках, подумать и создать проблемную ситуацию, вызывающую интерес к освоению материала». Именно учитель-субъект не побоится предоставить ученикам самостоятельность в поиске решения, пригласит учеников к оценке результатов учебного труда, расширит арсенал инструментов оценивания результатов учебной деятельности. При этом стоит сказать о том, что субъектность учителя - это не новое слово в педагогике, и до введения ФГОС она провозглашалась и признавалась. Однако ни руководители, ни педагоги не стремились к ее истинной реализации. После провозглашения новых стандартов субъектная позиция педагога стала обязательным требованием, закрепленным также и профессиональным стандартом педагогической деятельности.

Таким образом, субъектная, а стало быть, рефлексивная позиция, - это архиважное качество современного человека. В противном случае мы встречаемся с бессубъектностью, с отрицанием себя как активного субъекта. Отсутствие рефлексивных умений человека делает его объектом, которым можно легко манипулировать. Он подвержен влиянию средств массовой информации, политиков и окружающих, он не способен обеспечить свой индивидуальный образовательный и жизненный маршрут [5]. В целом для общества развитие рефлексии у его граждан является одним из главных условий устойчивого и оптимального (по форме, средствам и методам) развития. В связи с этим современная система образования является важнейшим инструментом инновационного развития, а задачи, перед ней стоящие, далеко выходят за рамки педагогики и требуют пристального внимания со стороны политиков всех уровней [5, с. 25].

Осознанное внедрение ФГОС действительно является важнейшей социально-политической задачей. Наступившее время социальных трансформаций требует качественного анализа и личностной рефлексии. Необходимо рационально исследовать «ненаблюдаемые» социальные трансформации в различных сферах жизни, особенно в образовании и воспитании человека, для того чтобы бы выстроить более углубленный процесс ценностно-мотивированной рефлексии отражения, обеспечить управляемый созидательный потенциал стратегического развития общества

\section{Baikal Research Journal}


[8, с. 43]. Уместными здесь являются слова У. Блейка «Чем выше форма жизни, тем глубже ее способность улавливать смысл и тем сильнее ее чувство жизни» [9, с. 135].

ФГОС нового поколения содержат описание планируемых результатов, которые отражают ожидания, связанные с уровнем достижения системой образования, образовательными учреждениями, педагогами, обучающимися, следующих основных результатов ступеней общего образования:

- формирование предметных и универсальных способов действий, а также опорной системы знаний;

- воспитание основ умения учиться - способности к самоорганизации с целью решения учебных задач;

- индивидуальный прогресс в основных формах личностного развития (эмоциональной, познавательной и саморегуляции).

В соответствии с концепцией и требованиями стандарта содержание планируемых результатов должно определять оценку предметных, метапредметных и личностных результатов образования в ходе разнообразных процедур: от текущей оценки учителем до различных аттестационных и неперсонифицированных процедур, выполняемых внешними службами. Определяется задача построения системообразующего элемента стандарта - системы оценки достижения планируемых результатов. При этом требуется включение учащихся в самостоятельную оценочную деятельность, развитие у них субъектности и навыков рефлексии, самоанализа, самоконтроля, адекватной и автономной самооценки учебных достижений (А. Г. Асмолов, А. М. Абрамов, А. М. Кондаков, Н. Д. Никандров).

В процессе обучения и воспитания следует вооружать ребенка средствами самопонимания, саморазвития в контексте взаимодействия с окружающими людьми, способами контрольно-оценочной деятельности, основанной на самооценивании образовательных достижений и понимании динамики собственного развития. Необходимым становится расширение и переориентация рефлексивной оценки собственных возможностей за пределы учебной деятельности в сферу самосознания и личностных качеств (Л. И. Божович, А. Г. Асмолов, А. М. Кондаков), создание рефлексивных механизмов поиска смысла деятельности.

И. В. Абакумова, П. Н. Ермаков, В. Т. Фоменко предлагают искать ответы на эти вопросы, прежде всего, в обучении, где элемент управления и стимуляции развития личности является обязательным атрибутом $[9 ; 10 ; 11]$. Из смысловой концепции сознания вытекает интерес педагогического свойства: смыслами как единицами сознания можно опосредованно управлять через включение личности в поток значимых деятельностей (А. Г. Асмолов, Б. С. Братусь) в личностно-значимую субъектно-порождающую учебную деятельность. Как отмечает И. В. Абакумова, трансформации смыслов, основательно проработанные на общепсихологическом уровне, практически не изучены применительно к учебной, познавательной деятельности учащихся. Поэтому в педагогическом мышлении возникают пробелы и явные смещения акцентов в реальном учебном процессе, проявляющиеся в невнимании к вопросам смыслообразования обучающихся [10, с. 10]. В. Т. Фоменко подчеркивает задачу интеграции получаемых ребенком знаний в школе, и доказывает, что разнохарактерные смыслы, соприкасаясь в одной познавательной структуре и взаимно влияя, могут порождать новый, многомерный смысл, обеспечивать самодифференциацию и самоиндивидуализацию в смыслообразующем обучении [9, с. 139].

Еще одним важным обстоятельством является то, что «в эпоху информатизационной социализации, - как пишет А. Г. Асмолов, - наши дети - это реальные “смыслочерпалки": они сначала вычерпывают смыслы, а потом уже черпают знания. Бесспорно, современной системе образования нужна смысловая педагогика" $[3 ; 4]$. В логике возникает вопрос о способах и технологиях привнесения в учебный

\section{Baikal Research Journal}

электронный научный журнал Байкальского государственного университета 
процесс такой смысловой составляющей, которая бы учитывала изменения характера общения учителя и современных детей в сторону возможного появления смыслового резонанса. А ведь он нужен! И тогда, во-первых, в задачу учителя входит инициация таких психолого-дидактических ситуаций, в процессе выхода из которых смыслы извлекаются, постигаются, осознаются, изменяются и обогащаются. Во-вторых, в подлинном учебном процессе возникает необходимость «добраться» до смысла изучаемого материала («смысл чего-то») и тем самым инициировать удивление или иное значимое эмоциональное состояние (радость, удовлетворение, горечь, переживание счастья и др.) - и это важно («всегда есть мой смысл»). В этом и есть ценностно-смысловая трансформация личности, запуск рефлексивных механизмов и понимание самого себя [12].

В проведенном исследовании преследовали определенную цель - определить эффективные условия формирования личностных результатов образовательной деятельности школьников, включающих мощное развитие рефлексии в структуре их самосознания и обеспечивающих становление субъектности, рефлексивности и самостоятельности. Мы убеждены, что учебная деятельность должна быть главным предметом рефлексии обучающегося, в результате этого появляется главный образовательный эффект - развивающееся самосознание. В ходе специально-организованных психолого-педагогических условий возможно расширение и переориентация рефлексивной оценки собственных возможностей ученика за пределы его учебной деятельности (в сферу личностных качеств и самосознания), нахождение смыслов этой деятельности.

Образовательные результаты могут включать следующие взаимосвязанные компоненты: учебные (академические) и личностные результаты. К планируемым результатам ФГОС в области личностного развития относятся: самоопределение (развитие Я-концепции, адекватной позитивной самооценки и самопринятия); морально-этическая ориентация (формирование моральной самооценки, развитие эмпатии, знание основных норм).

Среди личностных результатов можно определить рефлексивное самосознание, которое мы трактовали следующим образом:

- структурный компонент самосознания личности, имеющий системообразующий элемент (субъектную позицию и сущностные характеристики, среди которых можно выделить рефлексивную самооценку, самопринятие, самоконтроль, рефлексивность и эмпатийность) и появляющийся в определенных условиях деятельности личности;

- возрастное личностное образование, находящееся в динамике и связанное с вопросами саморазвития, самоопределения и самовоспитания. Как возрастное личностное образование может быть спроектировано в определенных условиях.

Мы считаем, что рефлексивное самосознание - это один из возможных личностных результатов образовательной деятельности, зафиксированный как компонент в структуре образовательных результатов, связанный с учебными результатами, при котором у учащегося расширяется и переориентируется рефлексивная оценка собственных возможностей за пределы учебной деятельности - в сферу личностных качеств и самосознания. Как личностный результат образования появляется в заданных условиях выполнения учебной деятельности, а именно в специально-организованных условиях образовательного процесса - в условиях изменения системы оценивания учебных результатов и применения рефлексивного управления учебной деятельностью [13].

В ходе исследования были выделены принципы организации учебной деятельности, которые определили специально организованные условия и комплекс организационно-содержательных действий по реализации условий (рис.).

\section{Baikal Research Journal}




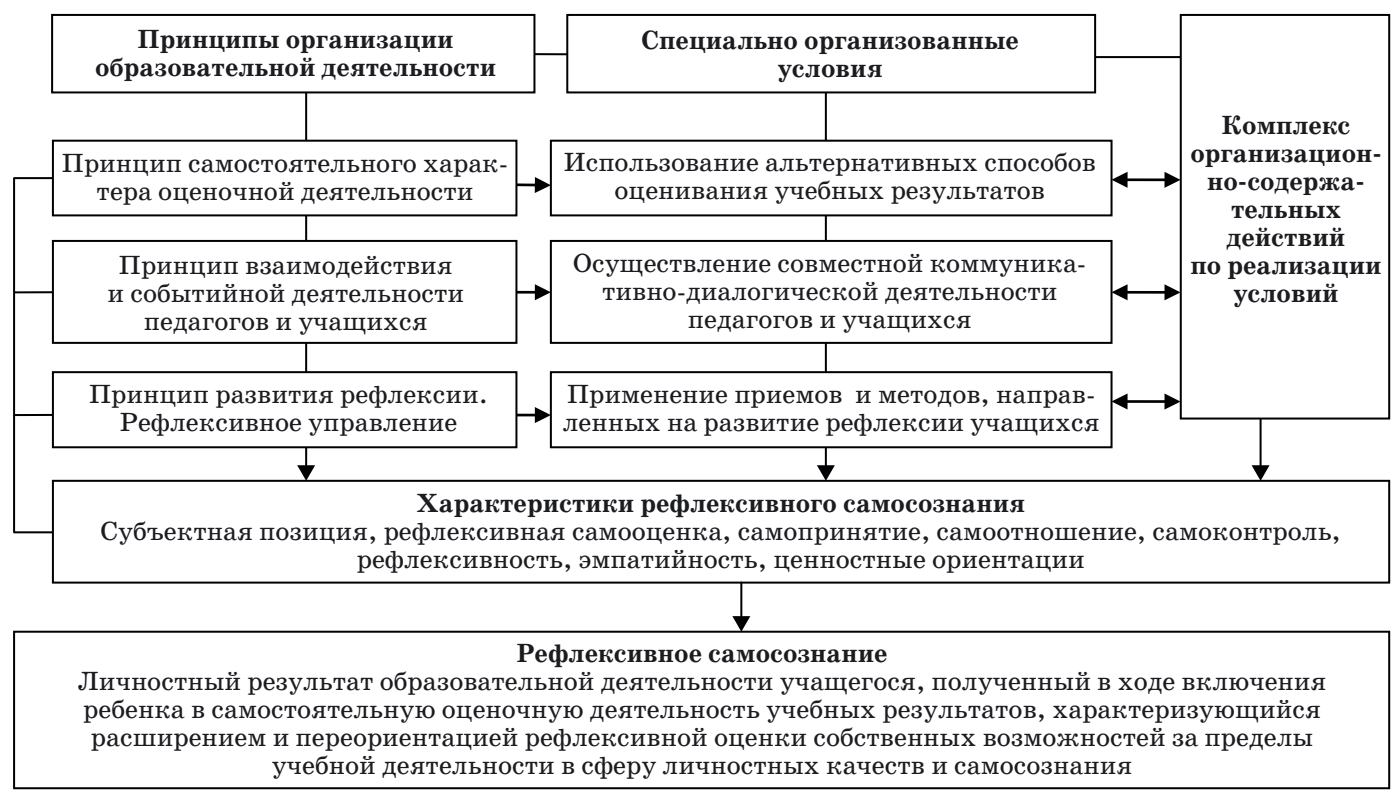

Принципы организации учебной деятельности

Особо следует остановиться на организационно-содержательных действиях, обеспечивающих реализацию третьего условия формирующего эксперимента «Применение приемов и методов, направленных на развитие рефлексии учащихся. Рефлексивное управление учебной деятельностью». Выделенный фокус внимания актуализирован тем, что отсутствие традиционной пятибалльной системы оценивания учебных результатов приводит к необходимости поиска новых способов оценивания и отслеживания того, что происходит со всеми участниками образовательного процесса в заданных условиях. Это обеспечивает, на наш взгляд, запуск их рефлексивных механизмов и процессов смыслопоиска.

В нашем комплексе была определена совокупность действий, среди которых можно выделить действие «Рефлексивные умения педагога». Ключевой являлась идея «у рефлексивного педагога - рефлексивные дети». Была поставлена задача развития рефлексивных умений педагогов, для выполнения которой разработали спецкурс «Рефлексивная культура педагога», ориентированный на повышение квалификации педагогов (72 ч.) в области рефлексивных процессов личности, на решение педагогических ситуаций, изучение методов развития рефлексии. Педагоги-участники формирующего эксперимента знакомились с философским пониманием и психологическим содержанием феномена рефлексии, рассматривали рефлексивное управление учением, характеризовали виды, формы рефлексии, сравнивали эффективность рефлексивного и нерефлексивного слушания, определяли собственный уровень сформированности педагогической рефлексии, анализировали и разрабатывали психолого-педагогические условия развития рефлексии учащихся.

Особое внимание было посвящено технологии рефлексивного управления, разработанной Т. И. Шамовой. Исследователь рассматривает развитие рефлексии учащихся в условиях реализации педагогом технологии рефлексивного управления деятельностью школьников и считает, что педагогическая деятельность, по своей сути, считается рефлексивной, а любые педагогические задачи являются задачами управления деятельностью учащегося. В отношении учащихся, замечает ученый,

\section{Baikal Research Journal}

электронный научный журнал Байкальского государственного университета 
корректно подчеркивать позицию субъекта, также способного к управлению своей деятельностью. Такого рода специфические процессы, отражающие одним человеком (педагогом) «внутреннюю картину мира» другого человека (учащегося), в ходе взаимодействия принято считать рефлексивными процессами [1]. При этом педагог должен не только рефлексивно отображать «внутреннюю картину мира", которой обладает учащийся, но и целенаправленно ее преобразовывать, углублять, развивать, учитывая активную деятельность самого ученика. В этом и заключается рефлексивное управление, которое, по мнению Т. И. Шамовой, составляет основу самосовершенствования педагогической деятельности, педагогического общения, профессионально-личностных свойств учителя.

Качественной характеристикой рефлексивного управления является тот факт, что результат взаимодействия управляющего и управляемого выражается в том, чтобы у последнего развивались способности к самоуправлению своей деятельностью. Сущностным свойством рефлексивного управления является делегирование многих полномочий и ответственности за результаты учебы и труда самим участникам образовательного процесса. Специфика управления состоит в том, что оно побуждает собственную активность и самостоятельность управляемых, влияет на процессы самоуправления и тем самым обеспечивает их субъектную позицию в образовательном процессе, реализуя партисипативное управление и взаимодействие.

Применительно к нашему исследованию под делегированием можно подразумевать стимулирование процессов самооценивания у учащихся путем активного привлечения их к выработке критериев оценивания и его осуществления; обеспечение сравнения ребенком своих достижений вчера и сегодня; предоставление ученику возможности осуществлять большое количество равнодостойных выборов, различающихся аспектом оценивания, способом действия.

Модель рефлексивного управления Т. И. Шамовой содержит четыре стадии, составляющие своеобразный цикл управления:

- стадия рефлексивного анализа;

- конструктивно-ориентационная стадия;

- стадия стабилизации;

- стадия системной рефлексии [1, с. 256-266].

Стадия рефлексивного анализа способствует выявлению и раскрытию субъектного опыта участников образовательного процесса, определению его желаемого состояния. Рефлексивный анализ не просто фиксирует начальное состояние личного опыта учащихся, но и дает картину того, как осуществляется взаимодействие педагога и учащихся, выявляя возможности обучающихся в том или ином виде самоуправленческой деятельности, определяет предпосылки включения субъектного опыта в образовательный процесс. Учащийся осуществляет самопознание, а педагогу далее важно на организационном и операционально-технологическом уровнях обеспечить наращивание его субъектных функций. Для этого, на наш взгляд, следует обеспечить внимательное наблюдение или истолкование того, что видит, слышит, чувствует субъект, получить обратную связь, которая может исходить как от окружающей среды, действий и используемого оборудования, так от других людей. Конструктивно-ориентационная стадия состоит в том, что на основе рефлексивного анализа обосновываются интенсифицирующие управленческие воздействия, обеспечивающие стимулирование учащихся в рамках своей учебной деятельности. При этом воздействие должно быть субъектно значимо, находиться в соответствии с опытом ученика. Стадия стабилизации заключается в обеспечении устойчивости реализации спроектированной деятельности по достижению совместно поставленных задач, в педагогической

\section{Baikal Research Journal}


поддержке учащихся. На стадии системной рефлексии происходит рефлексия учащимися учебного опыта своей деятельности, своей личности, деятельности педагога, осуществляется рефлексия педагогом своей деятельности и деятельности учащихся.

Например, в ходе формирующего эксперимента на стадии системной рефлексии учащиеся анализировали учебный опыт своей деятельности, свои личностные результаты и учебные достижения. Активно использовалась технология «Я», «Мы», «Дело»:

- «Я» - как чувствовал себя в процессе учения, было ли мне комфортно, с каким настроением работал, доволен ли собой (умение оценить свое физическое, эмоциональное состояние и чувства);

- «Мы» - насколько комфортно мне работалось в малой группе. Я помогал товарищам, они помогали мне - чего больше, какие у меня были затруднения в общении с группой;

- «Дело» - я достиг цели учения, мне этот материал нужен для дальнейшей учебы (для практики, просто интересно), в чем я затруднялся, как мне преодолеть свои проблемы.

Ребятам предлагались рефлексивные анкеты в форме незаконченных предложений для анализа чувств и состояний: «Я чувствовал...», «Я узнал...», «Я понял, осознал...». При этом необходимо было заполнить Дневник успеха (рефлексивный дневник) в соответствии с рубриками «Мои достижения», «Мои неудачи», «Мне понравилось», «Мне не понравилось», «Мне было интересно», «Я достиг» и др.

Кроме модели Т. И. Шамовой мы использовали коучинговую технологию, включающую этап постановки цели; этап обследования реальной ситуации; этап составления списка возможностей; этап принятия решения и составления плана действий. На наш взгляд, постановка открытых и продвигающих вопросов создает поле для свободы, творчества и создания ресурсного субъектного состояния, заметно может активизировать рефлексивную позицию и направить фокус внимания на будущее желаемое состояние.

Для этапа постановки иели это следующие вопросы: «Что ты хочешь?», «Что ты хочешь достичь?», «Если бы была возможность осуществить любое желание, то каким бы оно было?, «Насколько оно реалистично?», «Какой желаемый результат можно считать отличным?» .

На этапе обследования реальной ситуации главным становится отсутствие критики, более детальное описание целей субъекта. Мы предлагаем использовать следующие вопросы: «Что?», «Когда?», «Где?», «С кем?», «Кто?», «Как?», «Сколько?», «А еще?», «Если бы Вы знали ответ, то что бы сказали?», «Какие могут быть последствия для Вас и других?», «Какими критериями Вы пользуетесь?», «Что для Вас в этом самое трудное?», «Что бы Вы посоветовали другому, окажись он на Вашем месте?», "А что еще?», «Представьте себе диалог с самым мудрым человеком, которого Вы знаете, что он скажет Вам делать?», «Я не знаю, что делать дальше. А Вы?», «В чем Вы выиграете / проиграете, если так сделаете / скажете?», «Если бы так сказал / поступил кто-то другой, что бы Вы почувствовали / подумали / сделали?», «Что происходит на текущий момент?», «Какие есть причины считать, что это именно так?», «Какие внутренние препятствия или личностное сопротивление мешают Вашим действиям?», «Какие ресурсы уже у Вас есть?», «Какие дополнительные ресурсы Вам потребуются?» и др.

На этапе составления списка возможностей главным является поиск альтернативных способов действия. Количество вариантов важнее качества или возможности реализации каждого из них. Процесс поиска вариантов не менее важен, чем итог, так как он стимулирует мышление и развивает творческое на-

\section{Baikal Research Journal}


чало. Именно из этого широкого спектра творческих возможностей будут выбраны конкретные шаги. Предварительно необходимо создать спокойную атмосферу, в которой педагог / ученик могли бы свободно выражать свои мысли, высказывать идеи, не опасаясь критики. Не следует использовать такие фразы: «Это невозможно», «Это нельзя делать так» и т. д. Лучше использовать вопросы, которые начинаются со слов: «А что если...?». Например: «Что если бы Вы знали ответ? Каким бы он был?», «Что если бы этого препятствия не было? Как бы Вы поступили тогда?», «Кто мог бы помочь в этой ситуации?», «Что еще Вы можете сделать?».

На этапе принятие решения и составления плана действий целесообразно задать следующие вопросы: «Что Вы будете делать?», «Что станет первым шагом в выбранном варианте?», «Какой вариант Вы выберете?», «Каковы будут дальнейшие шаги?», «Когда Вы намереваетесь это сделать?» (указать точную дату), «Достигните ли Вы при этом своей цели?», «Какие возможны препятствия на пути? Как будете с ними справляться?», «Какая поддержка Вам нужна? Когда и как Вы собираетесь заручиться этой поддержкой?» .

Для научно-методического обеспечения исследуемой проблематики, заявленной темы и технологий были подготовлены учебные пособия «Рефлексивная культура педагога», прилагающийся к нему практикум с одноименным названием и учебное пособие «Рефлексивная культура личности руководителя школы как фактор эффективного взаимодействия субъектов в условиях трансформации образования».

Учебное пособие «Рефлексивная культура педагога» содержит теоретический блок, состоящий из двух разделов: «Философско-методологические и психолого-педагогические аспекты феномена рефлексии», «Педагогическая рефлексия как основной конструкт рефлексивной культуры педагога». Практикум «Рефлексивная культура педагога» включает практический блок «Семинарско-практические занятия и самостоятельная работа»; диагностико-прогностический блок «Изучение уровня рефлексивности личности»; методический блок «В методическую копилку педагога»; рефлексивный тренинг для педагогов по развитию рефлексивной культуры; контрольный блок, содержащий тематику рефератов и курсовых работ.

Блок «В методическую копилку педагога», содержащий описание методик, приемов, форм развития рефлексии учащихся, оказался востребованным для реализации обсуждаемого условия психолого-педагогического эксперимента. В него вошли этапы обучения рефлексии (по Г. А. Цукерман); рефлексивная карта и рефлексивные анкеты ученика; приемы развития форм письменной рефлексии учащихся (эссе, бортовой журнал, различные виды дневников, письменное интервью, синквейн, варианты портфолио); прием «двухрядный круглый стол»; методика организации рефлексии ученика на уроке; учебный журнал или дневник; подведение итогов урока; рефлексивный экран; упражнение «Плюс - минус - интересно»; «Дневник успеха»; рефлексивные технологии «Рефлексивная мишень», «Чемодан, корзина, мясорубка», «Все у меня в руках»; методика рефлексивного воспитания «Как подвести итоги четверти (года)»; методика проведения ситуационного рефлексивного классного часа «Итоги четверти» и др.

Учебное пособие «Рефлексивная культура личности руководителя школы как фактор эффективного взаимодействия субъектов в условиях трансформации образования» содержит описание коучинговых технологий, диагностический инструментарий и результаты эмпирических исследований.

Проведение теоретического исследования и формирующего эксперимента предоставило нам возможность получить научные и практические результаты,

\section{Baikal Research Journal}


которые мы уже обсуждали $[13 ; 14]$. По своей сути, результаты нашли отражение в Концепции стандартов нового поколения. Предлагаемые нами критерии и показатели рефлексивного самосознания, а также его содержательное наполнение имеют сходство с идеей блоков универсальных учебных действий и соответствуют задаче личностного развития учащегося в ходе учебной деятельности. Рефлексивное самосознание можно рассматривать как возможный значимый личностный результат образовательной деятельности учащегося, отражающий совокупность таких универсальных учебных действий, как личностное действие - самоопределение, самооценивание, нравственно-этическая оценка (обеспечивает личностный моральный выбор) и регулятивное универсальное действие - оценка и саморегуляция.

Разработанные критерии и показатели развития рефлексивного самосознания мы предлагаем использовать в работе образовательных организаций по определению динамики развития личностных и регулятивных универсальных учебных действий, в осуществлении неперсонифицированного мониторинга о достигаемых обучающимися образовательных и личностных результатов. В ходе формирующего эксперимента мы получили модель оценки результатов образования - педагогический мониторинг, выполняющий функцию контроля за уровнем академических знаний и неперсонифицированный (психологический) мониторинг личностного развития учащихся. Эта модель по смыслу соответствует разделу «Система оценки достижения планируемых результатов» Основной образовательной программы начального и основного общего образования.

В целом, результаты проведенного исследования свидетельствуют об эффективности применения технологий рефлексивного управления учебной деятельностью школьников в специально-заданных условиях изменения системы оценивания для получения значимых личностных результатов (рефлексивная самооценка и ее расширение в сферу самосознания) и личностных качеств (рефлексивная инициативность, самопринятие, самоконтроль, рефлексивность и эмпатийность, субъектная позиция, самостоятельность, позитивное самоотношение, ценностные ориентиры «Я - ценность», «Другой - ценность», «Ответственность - ценность»).

\section{Список использованной литературы}

1. Шамова Т. И. Управление образовательными системами / Т. И. Шамова, П. И. Третьяков, Н. П. Капустин ; под ред. Т. И. Шамовой. - М. : Академия, 2002. - 384 с.

2. Хуторской А. В. Методика личностно-ориентированного обучения. Как обучать всех по-разному? : пособие для учителя / А. В. Хуторской. - М. : Владос-Пресс, 2005. $383 \mathrm{c}$.

3. Асмолов А. Г. Образование - это проектирование будущего / А. Г. Асмолов // Образовательная политика. -2011 . - № 4. - С. 2-5.

4. Асмолов А. Г. Образование как ценностное полагание сотрудничества и свободного развития личности / А. Г. Асмолов // Новые ценности образования. - 2006. - Вып. 5-6. C. $5-11$.

5. Кондаков А. М. Образование 3.0. Новейшие тенденции современного образования [Электронный ресурс] / А. М. Кондаков. - Режим доступа : http: //www.togirro.ru/assets/ files/Mediateka/Mart_KONF_DROFA/education_3_0_Kondakov.pptx.

6. Робский В. Педагогическая рефлексия / В. Робский // Директор школы. - 2015. № $6 .-$ C. $23-30$.

7. Галеева А. Новый профессиональный стандарт как ресурс развития профессиональной компетентности педагога / А. Галеева // Методическая работа в школе. - 2015. № $2(34)$. - C. $7-12$.

8. Поташник М. Работать по-фгосовски / М. Поташник, М. Левит // Директор школы. 2016. 一 № 1. - C. 45-50.

\section{Baikal Research Journal}


9. Филонов Г. Н. Рефлексивный потенциал социальных трансформаций / Г. Н. Филонов // Педагогика. - 2013. - № 7. - С. 43-50.

10. Абакумова И. В. Новодидактика / И. В. Абакумова, П. Н. Ермаков, В. Т. Фоменко. М. : Кредо, 2013. - Кн. 1 : Методология и технологии обучения: в поисках развивающего ресурса. - $162 \mathrm{c}$.

11. Абакумова И. В. Смысловая дидактика: новая интерпретация классических понятий / И. В. Абакумова, П. Н. Ермаков // Гуманизация образования. - 2008. — № 3. - С. 9-19.

12. Эпова Н. П. Ценностно-смысловые детерминанты психического развития личности в условиях трансформации российского образования : научная статья / Н. П. Эпова, А. Х. Сундукова, Л. Г. Захарова // Известия Южного федерального университета. Педагогические науки. - 2015. - № 7. -С. 43-52.

13. Терехова Т. А. Психолого-педагогические условия развития рефлексивного самосознания у учащихся / Т. А. Терехова, Н. П. Эпова // Вестник Бурятского государственного университета. - 2012. - Спецвып. D. - C. 151-156.

14. Эпова Н. П. Самоотношение как важный компонент рефлексивного самосознания учащихся в условиях специально-организованной среды учебной деятельности / Н. П. Эпова // Вестник Читинского государственного университета. — 2007. — № 4 (45). — С. 134-142.

\section{References}

1. Shamova T. I., Tret'yakov P. I., Kapustin N. P. Upravlenie obrazovatel'nymi sistemami [Management of educational systems]. Moscow, Akademiya Publ., 2002. 384 p.

2. Khutorskoi A. V. Metodika lichnostno-orientirovannogo obucheniya. Kak obuchat' vsekh po-raznomu? [Technique of the personal focused training. How to train all differently?]. Moscow, Vlados-Press Publ., 2005. 383 p.

3. Asmolov A. G. Education is a design of the future. Obrazovatel'naya politika = Educational Policy Journal, 2011, no. 4, pp. 2-5. (In Russian).

4. Asmolov A. G. Education as valuable polaganiye of cooperation and free development of the personality. Novye tsennosti obrazovaniya = New Educational Values, 2006, iss. 5-6, pp. 5-11. (In Russian).

5. Kondakov A. M. Obrazovanie 3.0. Noveishie tendentsii sovremennogo obrazovaniya [Education 3.0. The newest tendencies of modern education. Available at: http: //www.togirro. $\mathrm{ru} /$ assets/files/Mediateka/Mart_KONF_DROFA/education_3_0_Kondakov.pptx. (In Russian).

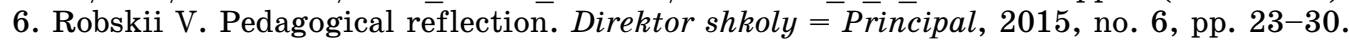
(In Russian).

7. Galeeva A. New professional standard as resource of development of professional competence of the teacher. Metodicheskaya rabota $v$ shkole $=$ Methodical work at school, 2015, no. 2 (34), pp. 7-12. (In Russian).

8. Potashnik M., Levit M. To work on-fgosovski. Direktor shkoly = Principal, 2016, no. 1, pp. 45-50. (In Russian).

9. Filonov G. N. The reflexive potential of social transformations. Pedagogika= Pedagogics, 2013, no. 7, pp. 43-50. (In Russian).

10. Abakumova I. V., Ermakov P. N., Fomenko V. T. Novodidaktika [New didactics]. Moscow, Kredo Publ., 2013. B. 1. 162 p.

11. Abakumova I. V., Ermakov P. N. Semantic didactics: new interpretation of classical concepts. Gumanizatsiya obrazovaniya = Humanization of Education, 2008, no. 3, pp. 9-19. (In Russian).

12. Epova N. P., Sundukova A. Kh., Zakharova L. G. Value-notional determinants of mental development of a person in the context of transformation of the Russian education. Izvestiya Yuzhnogo federal'nogo universiteta. Pedagogicheskie nauki = Bulletin of Southern Federal University. Pedagogical sciences, 2015, no. 7, pp. 43-52. (In Russian).

13. Terekhova T. A., Epova N. P. Psychological and pedagogical conditions of pupil's reflexive self-consciousness. Vestnik Buryatskogo gosudarstvennogo universiteta = Bulletin of Buryat State University, 2012, iss. SD, pp. 151-156. (In Russian).

14. Epova N. P. The self-relation as an important component of reflexive consciousness of pupils in the conditions of the special and organized environment of educational activity. Vestnik Chitinskogo gosudarstvennogo universiteta = Bulletin of Chita State University, 2007, no. 4 (45), pp. 134-142. (In Russian).

\section{Baikal Research Journal}




\section{Информация об авторе}

Эпова Надежда Павловна - кандидат психологических наук, доцент, кафедра управления образованием, Ростовский институт повышения квалификации и профессиональной переподготовки работников образования, 344011, г. Ростов-на-Дону, пер. Гвардейский, 2; e-mail: epova_70@mail.ru.

\section{Author}

Nadezhda P. Epova - PhD in Psychology, Associate Professor, Chair of Education Management, Rostov Institute of Training and Professional Retraining of Educators, 2 Gvardeysky Lane, 344011, Rostov-on-Don, Russian Federation; e-mail: epova_70@mail.ru.

\section{Библиографическое описание статьи}

Эпова Н. П. Психолого-педагогические аспекты рефлексивного управления учебной деятельностью обучающихся в условиях изменения системы оценивания при формировании личностных результатов / Н. П. Эпова // Baikal Research Journal. — 2016. — T. 7, № 4. DOI : $10.17150 / 2411-6262.2016 .7(4) .26$.

\section{Reference to article}

Epova N. P. Psychological and pedagogical aspects of reflexive management of school students' educational activity in terms of changing assessment system in developing personal results. Baikal Research Journal, 2016, vol. 7, no. 4. DOI : 10.17150/2411-6262.2016.7(4).26. (In Russian).

\section{Baikal Research Journal}

